The results obtained are such that it can now be said with some assurance that the recovery of large areas of valuable land from the tsetse-fly has become economically feasible under the control of specially trained men ; and it is to be hoped that the Depart. ment that Swynnerton built up will be allowed to continue its separate existence and carry on the great work for Africa which he initiated.

GuY A. K. Marshall.

\section{Mr. B. D. Burtt}

THE tragic loss, through an aeroplane disaster, of Mr. C. F. M. Swynnerton, Director of the Tsetse Research Department, and of Mr. B. D. Burtt, botanist to the Department, robs East Africa, at one blow, both of a distinguished zoologist and administrator and of a field worker who had a more intimate knowledge of the vegetation of Tanganyika, and probably of East Tropical Africa as a whole, than any other living botanist. The loss is the greater since news had just been received that the work of the Department was to be extended.

Bernard Burtt was the son of Dr. A. H. Burtt of York, who was himself a botanist. Young Burtt, who was born in 1902, was educated at the Friends' School, Ackworth, and at University College, Aberystwyth, and came to Kew in 1923. He did not shine in examinations, but as an all-round naturalist he was outstanding. Although he held a temporary post in the Kew Herbarium, his real interest was in the open-the living collections, the local insect fauna, and the bird-life in Richmond Park. Later he assisted his cousin, Dr. J. Burtt Davy, who was preparing the first volume of his "Flora of the Transvaal". Burtt's opportunity came when the tsetse fly campaign was organized. The writer well remembers Swynnerton visiting the Herbarium in search of a botanist for field work in Tanganyika. Burtt's services were pressed with every confidence. $\mathrm{He}$ went out to East Africa in 1925 as District Reclamation Officer, an appointment in the Tsetse Reclamation branch of the Game Preservation Department. When that branch later became the independent Department of Tsetse Research, he became the survey botanist for that Department. He threw himself with all his enthusiasm into the work, the interrelationships of the fly, the game and the vegetation, and it is doubtful which of the three held the greatest attraction, for one possessed, as he was, of such intense biological interests and sporting instincts. Though not the official ecologist to the Survey he became an ecologist in the widest sense. At the same time he always appreciated and fostered taxonomic studies, both botanical and entomological.

Burtt was an excellent collector. His herbarium material was usually sufficient for a five-fold distribution; a set each for Kew, the British Museum and the Imperial Forestry Institute, Oxford, a fourth and fifth set being retained in Africa for Amani and for his own Department. The collections as a whole were dealt with at Kew, though specialists at South Kensington and Oxford helped in the identification of their respective groups. Burtt's energies taxed the Kew staff to its utmost, one of his last sendings consisting of thirty-one cases. His material was always good, and often represented little-known or new species. But though he collected many novelties, they were not his first interest. $\mathrm{He}$ was concerned with the vegetation as a whole, the component species and the fly, though he was quick to spot a "beautiful new species", as he fondly termed them. He did not care for writing, and published little. When on leave, mountain exploration always had a strong appeal; he collected on Hanang and the Ngoro-Ngoro crater and surrounding mountains, besides the better known summits, and he was probably the only British botanist to climb and collect on the difficult ground of the old crater of Mount Meru.

Latterly Burtt travelled much by air, surveying the vegetation and the haunts of various species of tsetse-fly. In order to see more of Central Africa he curtailed his last leave and travelled back to Tangan. yika by car with a friend by way of Nigeria, French Cameroons, Belgian Congo, Ituri Forest, Kivu and Uganda, and of this he has left a graphic account. His love of fun, kindheartedness and fondness of children were evidences of a most attractive personality. Always abounding in energy and good spirits, he was exactly the man for the post, and his loss will be severely felt not only by botanical institutions in Britain but very specially by the Department of Tsetse Research. As a correspondent in the Territory writes : "I do not know how the Department will fill his place, for not only had he a unique knowledge of our country's flora, but he had to an unusual extent the gift of enthusing others". $\quad$ A. D. C.

THe above accounts of the loss which science in general, and East African science in particular, has sustained in the untimely deaths of Mr. Swynnerton and Mr. Burtt, have come from two writers who are in a far better position than $I$ to appraise the magnitude of that loss. As one who has worked for the last thirteen years under the direction of the one and in constant close association with the other, I am glad of this opportunity to add a few words about them in their capacities as leader and colleague. Mr. Swynnerton, in addition to displaying the qualities which have been described above, so treated his staff that they one and all looked to him more as guide, philosopher and friend than as to an official superior; he was an inspiration to greater and ever greater efforts to achieve the objects for which his Department was created, and by his kindly appreciation of all efforts, even the smallest, made each feel that his contribution formed a vital part of the general scheme. He never asked from anyone more than he was prepared to perform himself, and his visits to lonely workers were like an invigorating tonic, difficulties which had previously seemed insuperable disappearing, for the time at least, under his magic touch. His work was inspired by a genuine love for the Africans in whose country he spent so much of his life and his treatment of them was characterized by a patriarchal attitude in the best sense of that word. 